\title{
THE DOWNY WILLOW (SALIX LAPPONUM L.) POPULATION ON THE PEAT BOG NEAR LAKE BIKCZE (LECCZYŃSKO-WLODAWSKIE LAKELAND)
}

\author{
Magdalena Pogorzelec \\ Department of General Ecology, University of Life Sciences, Akademicka 15, 20-950 Lublin, Poland \\ e-mail: m.pogorzelec@op.pl
}

Received: 5.12.2007

S u m m a r y

Studies carried out in 2001-2003 were aimed at evaluation of the current structure and conditions of the population along with the recording of biometric traits of downy willow specimens at their natural stand on Lake Bikcze.

It has been found that the population of downy willow on the peat bog near Lake Bikcze has much increased since the 1950 's. The character of phytocoenoses, where Salix lapponum occurred most abundantly, may prove its wide requirements in terms of habitat conditions. S. lapponum specimens were in good condition. Furthermore, blooming of male and female specimens as well as great viability of pollen grains was recorded. High variability of selected biometric traits for studied species' specimens was found.

Key words: Salix lapponum, population's structure, condition, biometric traits

\section{INTRODUCTION}

Boreal species of vascular plants make up a relatively large percentage in the flora of ŁęczyńskoWłodawskie Lakeland: there are 149 species on over 1000 stands (in peat bog, aquatic, forest, and xerothermic ecosystems). Most of those stands are located at the edge of the geographic range of boreal species ( $\mathrm{M} \mathrm{i} \mathrm{t} \mathrm{k} \mathrm{a,}$ 1997; F i jałk ow s ki and L orens, 1998).

Despite of the fact that many rare plant species enjoy complete legal protection, most of them are threatened with extinction, which is associated with their low tolerance towards changing habitat conditions (Kaźmi e r c zak ow a and Zarzy cki, 2001).

Salix lapponum L. (downy willow) is boreal relics, a rare and extremely threatened species due to a gradually decreasing number of its stands as well as an alarming decrease of its population in Poland (K a ź m i e r c z a k ow a and Zar z y c k i, 2001). The largest number of its lowland stands remained within Łęczyńsko-Włodawskie Lakeland. The first and only (in the $20^{\text {th }}$ century) study on downy willow ecology and distribution was made just for that area in 1958 by Fijałk ow ki. His observations have not been verified up to date, meanwhile in 1996 Salix lapponum was considered to be a species threatened by extinction in the Lublin region ( $\mathrm{F} \mathrm{i} \mathrm{j} \mathrm{ałk} \mathrm{o} \mathrm{w} \mathrm{s} \mathrm{k} \mathrm{i,} \mathrm{1996).}$

Within Łęczyńko-Włodawskie Lakeland, the most numerous population of $S$. lapponum can be found on Lake Bikcze. The present study was aimed at evaluating the current structure and condition of that population, as well as documenting biometric traits of downy willow specimens.

\section{MATERIALS AND METHODS}

The observations were made in 2001-2003 on the peat bog adjacent to the western edge of Lake Bikcze in Łęczyńsko-Włodawskie Lakeland.

The first stage of the study consisted in determining 7 research plots $(A, B, C, D, E, F, G)$ of size $\left(60-750 \mathrm{~m}^{2}\right)$ and shape dependent on the quantity and distribution of $S$. lapponum specimens in particular peat bog fragments (Fig. 1). Detailed floristic lists were made and analyzed in syntaxonomic view to characterize phytocoenoses in the studied area. Current botanical nomenclature was given after $\mathrm{M}$ ir e k et al. (2002), and phytosociological one after M a t u s z k i e w i c z (2001).

Following procedures were made in every area in order to record the quantity and quality of the downy willow population:

- the number of Salix lapponum specimens in the studied area and its surroundings;

- the condition of Salix lapponum in its stands using original subjective 3 -grade shoot status classification taking into account characteristic conformation and general health of plants (P o g o r z e l e c , 2004);

- the ratio of female to male $S$. lapponum specimens (during the blooming at the end of March and the beginning of April 2003); 
- pollen grains of Salix lapponum were collected in April 2004; it served to determine its viability. Typical acetocarmine microscopic preparations were made using fresh pollen at the collection site. Acetocarmine dying protoplasts of live pollen grains to red color allowed for excluding their sterility. The preparations were analyzed using a light microscope. The percentage of live pollen grains was calculated. In order to decrease errors to a minimum, 2 preparations were made from each of 7 samples, and then every 300 grains were analyzed in each.

- biometric measurements of over 100 plants were made taking into account the following: stem height, height of leafy top of stem, number of leaves, length and width of leaf located in the middle of stem (at $0.1 \mathrm{~cm}$ accuracy).

Every above-ground stem, regardless of the underground connections, was considered as a specimen.

The survey was updated every year focusing on changes in stems of the $S$. lapponum population in each research stations as well as changes in the plants' condition in the studied populations.

General characteristics (median, lower and upper quartiles, range, minimum, and maximum values) were calculated for variables measured in the quotient scale.

\section{RESULTS}

The population of downy willow on Lake Bikcze has much increased since the 1950's. A total of over 5000 specimens were recorded in 2001-2003 (Tab. 1). The stand of the studied species was located on a transitional bog. Salix lapponum occurred most frequently together with plant species characteristic for associations from Phragmitetea, Scheuchzerio-Caricetea nigrae, Chcycoc-
co-Sphagnetea, Molinio-Arrhenatheretea, and Alnetea glutinosae classes (Tab. 2, Fig. 2).

Evaluation of particular downy willow specimens revealed their general good condition, which slightly oscillated during two-year observations (Tab. 1, Fig. 3).

Specimens of Salix lapponum bloomed and fruited in all the plots and the whole stand on Lake Bikcze (Figs 4, 5); the determination of sex structure within the population was then possible. Female specimens dominated at the ratio of $3: 2$ in the whole population (Tab. 1).

The pollen grain viability study indicated that it was often higher than $90 \%$ in the samples, which proves that there was a possibility of sexual reproduction within the studied population.

Great differentiation of Salix lapponum stem architecture was observed in the stand on Lake Bikcze. The height of the above-ground part of stems varied from 25 to $155 \mathrm{~cm}$, which probably depended on the age and light access in the habitat. The length of the leafy stem's top was from 7 up to $85 \mathrm{~cm}$, which depended on the plant's age (older plants produce more side shoots located in the upper fragment of the main stem). The number of leaves in the studied species ranged from 40 to 450 and depended on the development level of the leafy stem's top which is usually more branched and has more leaves in older specimens. A highly significant statistical association between stem height and number of leaves on them was found: the dependence is proportional - the higher plant, the more leaves it produces. The length of leaves sampled from the middle part of the stem varied (from 2.5 to $8.9 \mathrm{~cm}$ ), and their width was 1.63 $\mathrm{cm}$, on average (Tab. 3).

Table 1

Salix lapponum in research stations on Lake Bikcze.

\begin{tabular}{|c|c|c|c|c|c|c|c|c|}
\hline Study area & & $\mathbf{A}$ & B & $\mathbf{C}$ & D & $\mathbf{E}$ & $\mathbf{F}$ & G \\
\hline Size of study area $\left(\mathrm{m}^{2}\right)$ & & 600 & 750 & 60 & 370 & 330 & 200 & 160 \\
\hline \multirow{2}{*}{ Number of shoots } & 2001 & 223 & 8 & 10 & 3000 & 394 & 111 & 200 \\
\hline & 2002 & 341 & 8 & 10 & 3514 & 396 & 111 & 235 \\
\hline \multirow{2}{*}{ Maximum height of shoots $(\mathrm{cm})$} & 2001 & 110 & 120 & 110 & 180 & 95 & 135 & 200 \\
\hline & 2002 & 120 & 90 & 100 & 130 & 130 & 145 & 155 \\
\hline \multirow{2}{*}{ Specimen condition (1-3) } & 2001 & 2 & 3 & 3 & 3 & 2 & 2 & 2 \\
\hline & 2002 & 2 & 2 & 2 & 3 & 3 & 2 & 1 \\
\hline $\begin{array}{l}\text { Ratio of female to male } \\
\text { blooming shoots }+:{ }^{\lambda}\end{array}$ & 2003 & $2: 3$ & $0: 1$ & $2: 1$ & $1: 1$ & $3: 1$ & $3: 1$ & $1: 0$ \\
\hline
\end{tabular}


Table 2

Floristic composition of phytocoenoses with Salix lapponum occurrence in the plots in the years 2002 and 2003.

\begin{tabular}{|l|c|c|c|c|c|c|c|c|c|c|c|c|c|c|}
\hline & \multicolumn{2}{|c|}{ A } & \multicolumn{2}{|c|}{ B } & \multicolumn{2}{|c|}{ C } & \multicolumn{2}{|c|}{ D } & \multicolumn{2}{|c|}{ E } & \multicolumn{3}{|c|}{ F } & \multicolumn{2}{|c|}{ G } \\
Plots & 02 & 03 & 02 & 03 & 02 & 03 & 02 & 03 & 02 & 03 & 02 & 03 & 02 & 03 \\
Year & 26 & 29 & 23 & 24 & 14 & 14 & 16 & 15 & 19 & 17 & 18 & 18 & 21 & 20 \\
Number of vascular plants & 10 & 10 & - & - & - & - & 40 & 40 & 20 & 20 & + & + & 40 & 40 \\
Layer a density (\%) & 40 & 40 & 10 & 10 & 10 & 10 & 60 & 70 & 70 & 70 & 70 & 80 & 60 & 60 \\
Layer b density (\%) & 70 & 70 & 60 & 60 & 70 & 70 & 50 & 50 & 60 & 60 & 20 & 20 & 30 & 30 \\
Layer c coverage (\%) & 30 & 30 & 40 & 40 & 40 & 40 & 60 & 60 & 70 & 70 & 50 & 50 & 40 & 40 \\
Layer d coverage (\%) & & & & & & &
\end{tabular}

\section{Cl. Phragmitetea}

Calla palustris L.

Carex pseudocyperus $\mathrm{L}$.

Carex rostrata Stokes

Equisetum fluviatile $\mathrm{L}$.

Galium palustre L.

Lysimachia thyrsiflora $\mathrm{L}$.

Peucedanum palustre (L.) Moench

Phragmites australis (Cav.) Trin. ex Steued

Ranunculus lingua $\mathrm{L}$.

Typha angustifolia $\mathrm{L}$.

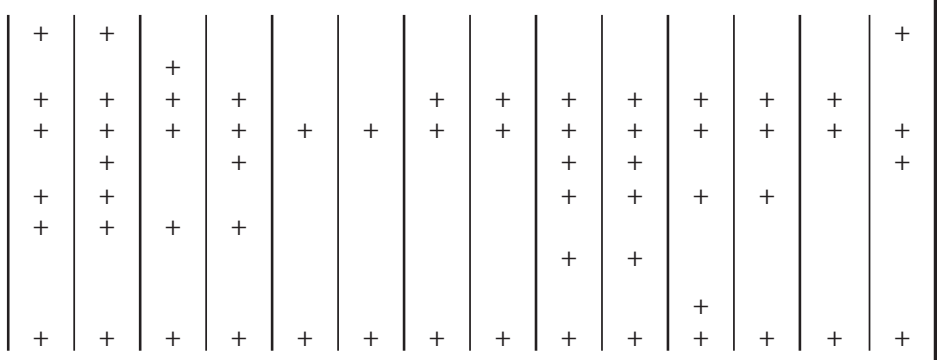

\section{Cl. Scheuchzerio-Caricetea nigrae}

Carex lasiocarpa Ehrh.

Carex limosa L.

Carex nigra Bell. et All.

Comarum palustre $\mathrm{L}$.

Eriophorum angustifolium Honck.

Juncus articulatus L.

Eriophorum latifolium Hoppe

Menyanthes trifoliata L.

Stellaria palustris Retz.

\section{Cl. Oxycocco-Sphagnetea}

Andromeda polifolia L.

Drosera rotundifolia L.

Eriophorum vaginatum $\mathrm{L}$.

Oxycoccus palustris Pers

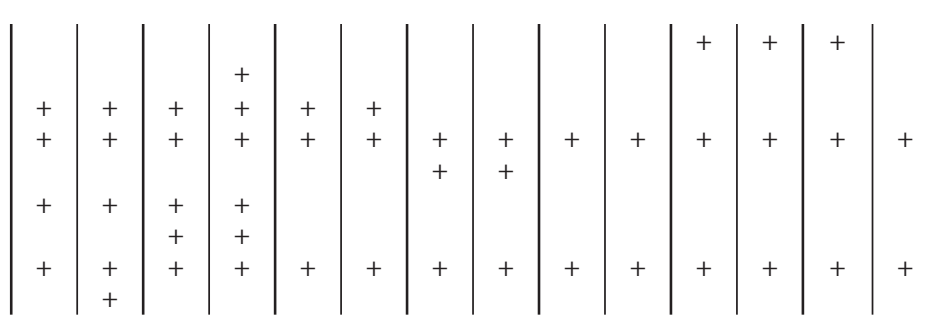

\section{Cl. Molinio-Arrhenatheretea}

Caltha palustris L.

Galium uliginosum Willd.

Juncus conglomerates $\mathrm{L}$.

Lysimachia vulgaris $\mathrm{L}$.

Lythrum salicaria L.

Molinia coerulea (L.) Moench
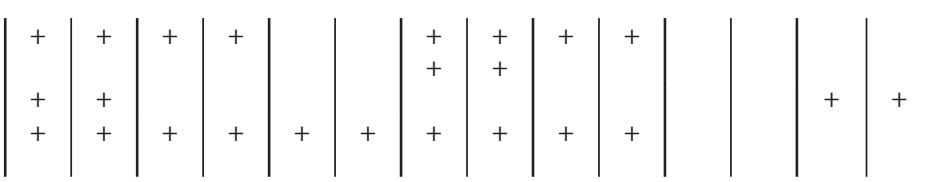

\section{Cl. Alnetea glutinosae}

Alnus glutinosa (L.) Gaertn. a

Betula humilis Schrk. b

Calamagrostis canescens (Web.) Roth

Salix cinerea L. b

Salix pentandra L. b

Salix rosmarinifolia L. $\mathbf{b}$

Thelypteris palustris (L.) A. Gray

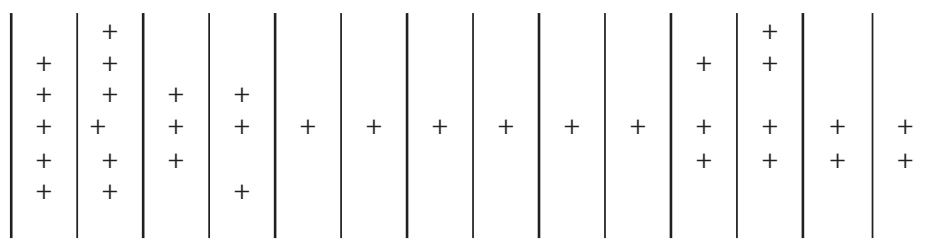

\section{Other species}

Betula pendula Roth a

Betula pendula Roth. $\mathbf{b}$

Betula pubescens Ehrh. a

Betula pubescens Ehrh. b

Lemna minor $\mathrm{L}$.

Pinus sylvestris L. $\mathbf{b}$

Plagiomnium cuspidatum (Hedw.) Kop. d

Populus tremula L. a

Salix lapponum L. b

Sphagnum sp.d

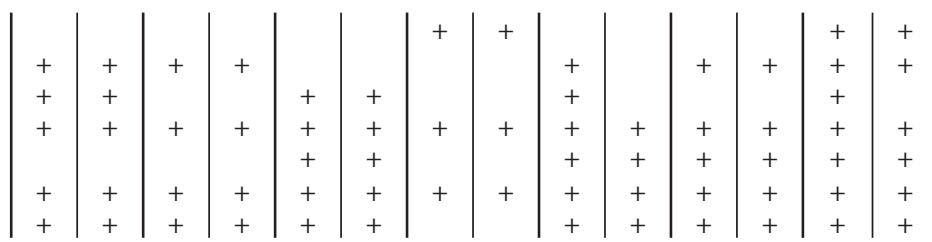


Table 3

Descriptive statistics of morphometric traits of Salix lapponum specimens in the stand on Lake Bikcze.

\begin{tabular}{|c|c|c|c|c|c|c|c|c|}
\hline & $\begin{array}{c}\text { Number of } \\
\text { samples }\end{array}$ & $\begin{array}{c}\text { Mean } \\
\text { value }\end{array}$ & $\begin{array}{c}\text { Standard } \\
\text { deviation }\end{array}$ & Median & $\begin{array}{c}\text { Lower } \\
\text { quartile }\end{array}$ & $\begin{array}{c}\text { Upper } \\
\text { quartile }\end{array}$ & Min & Max \\
\hline $\begin{array}{c}\text { A } \\
\text { Height of above-ground } \\
\text { part of shoot (cm) }\end{array}$ & 104 & 81.34 & 27.11 & 80.00 & 60.00 & 100.00 & 25.00 & 155.00 \\
\hline $\begin{array}{c}\text { B } \\
\text { Height of leafy top (cm) }\end{array}$ & 104 & 36.29 & 15.02 & 35.00 & 26.00 & 46.50 & 7.00 & 85.00 \\
\hline B : A & 104 & 0.46 & 0.17 & 0.44 & 0.36 & 0.57 & 0.12 & 0.89 \\
\hline $\begin{array}{c}\text { C } \\
\text { Leaf length (cm) }\end{array}$ & 104 & 5.16 & 1.31 & 4.90 & 4.20 & 6.10 & 2.50 & 8.90 \\
\hline $\begin{array}{c}\text { D } \\
\text { Leaf width (cm) }\end{array}$ & 104 & 1.63 & 0.80 & 1.60 & 1.30 & 1.90 & 0.30 & 8.00 \\
\hline D : C & 104 & 0.32 & 0.17 & 0.32 & 0.26 & 0.36 & 0.07 & 1.86 \\
\hline Number of leaves & 104 & 144.39 & 75.99 & 120.00 & 99.50 & 160.00 & 40.00 & 450.00 \\
\hline
\end{tabular}

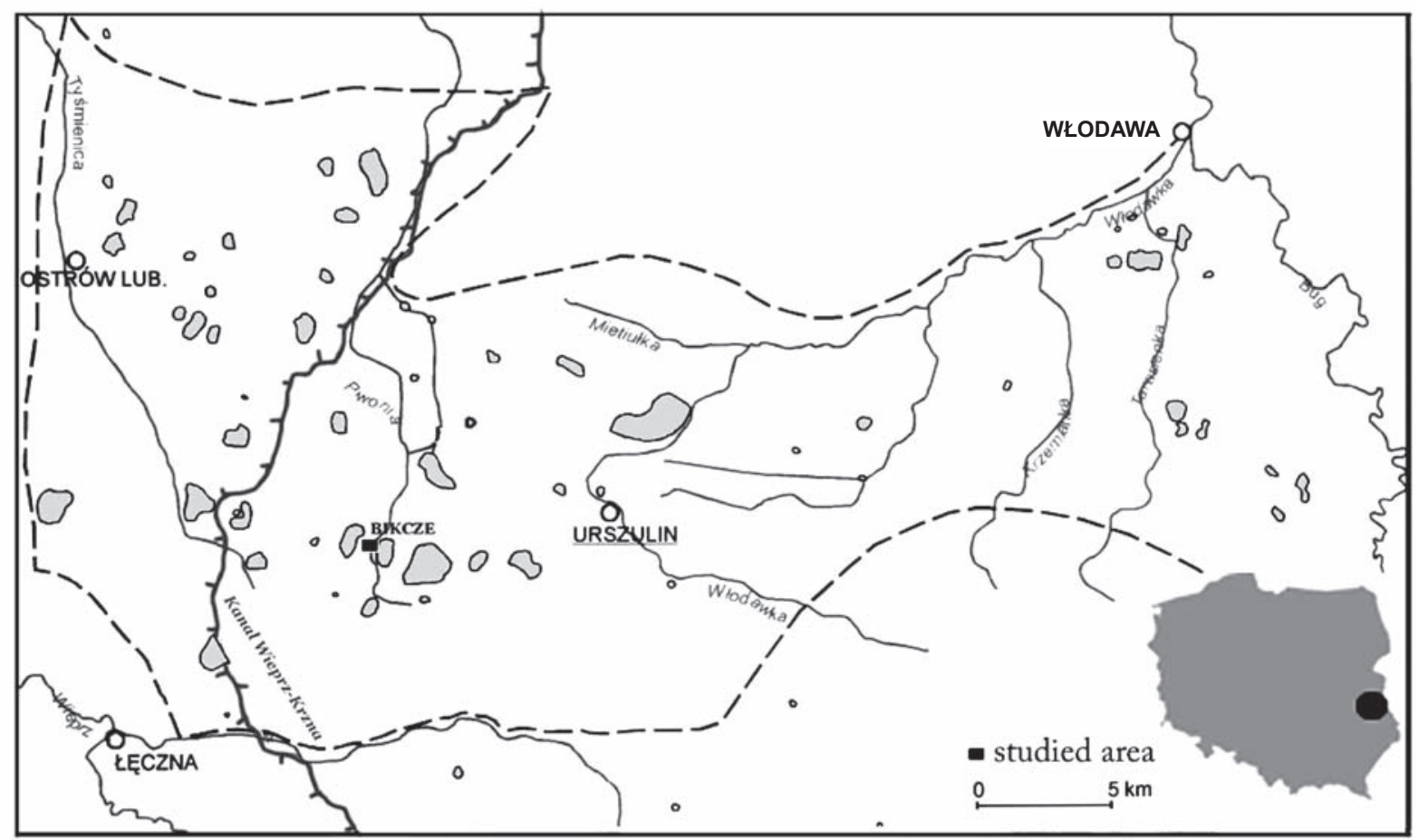

Fig. 1. Location of the study area in Łęczna-Włodawa Lakeland.

\section{DISCUSSION}

F i j a łk ow s ki (1958) took note of the fact that Salix lapponum stands were located mainly on hardly accessible areas, not damaged due to human activity. In the author's opinion, favorable conditions, mainly dependent on the system of ecological factors that make the downy willow development easier, occurred most often on the lake's edge (probably primary stands), rarely on wide peat bogs (probably secondary stands). The largest arrangements of downy willow were described on peat bogs adjacent to LakesBiałe Sosnowickie, Czarne Gościnieckie, Miejskie, Gumienko, Orzechówek, Moszne, Długie, Wytyckie, Łukie, Spilno-Koseniec, and Dube- 


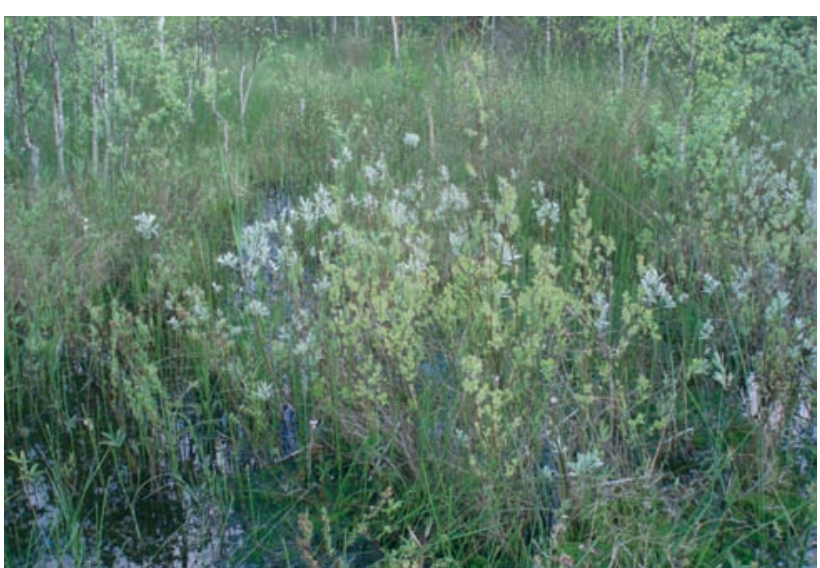

Fig. 2. Phytocenosis with Salix lapponum on peat-bog near Bikcze Lake.

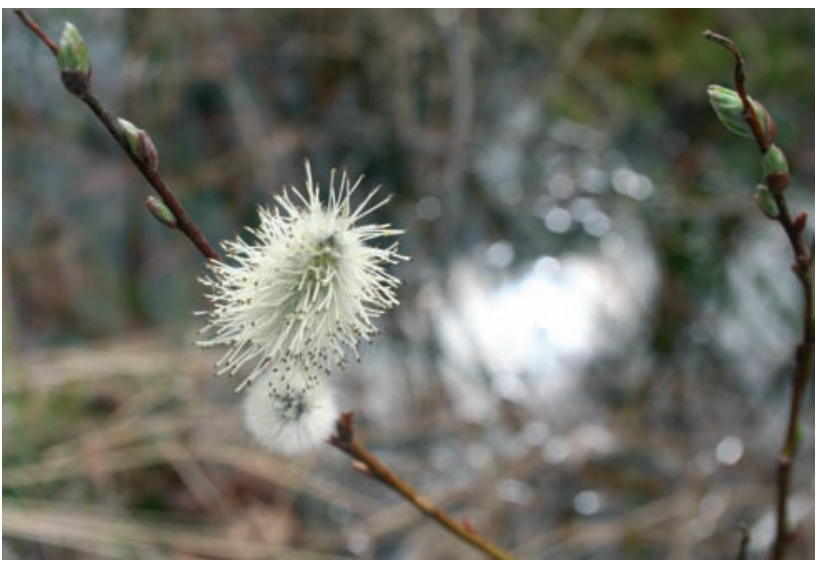

Fig. 4. Salix lapponum blooming male individual.

czyńskie. F i jałk ow ski (1958) recorded the occurrence of S. lapponum in small groups from 10 to 50 specimens on the peat bog near Lake Bikcze.

The original studies carried out in 2001-2003 confirmed the occurrence of a much larger population of downy willow in the studied area (about 5000 specimens). S. lapponum specimens were characterized by good condition, which may prove appropriate habitat conditions for its growth and development in the studied stand.

The reason for the population increase might result from the change of habitat conditions associated with hydrotechnical reconstruction of that area. Lake Bikcze is situated in a wide depression of agriculturally used area near the village of Rozplucie-Grabów. The lake's

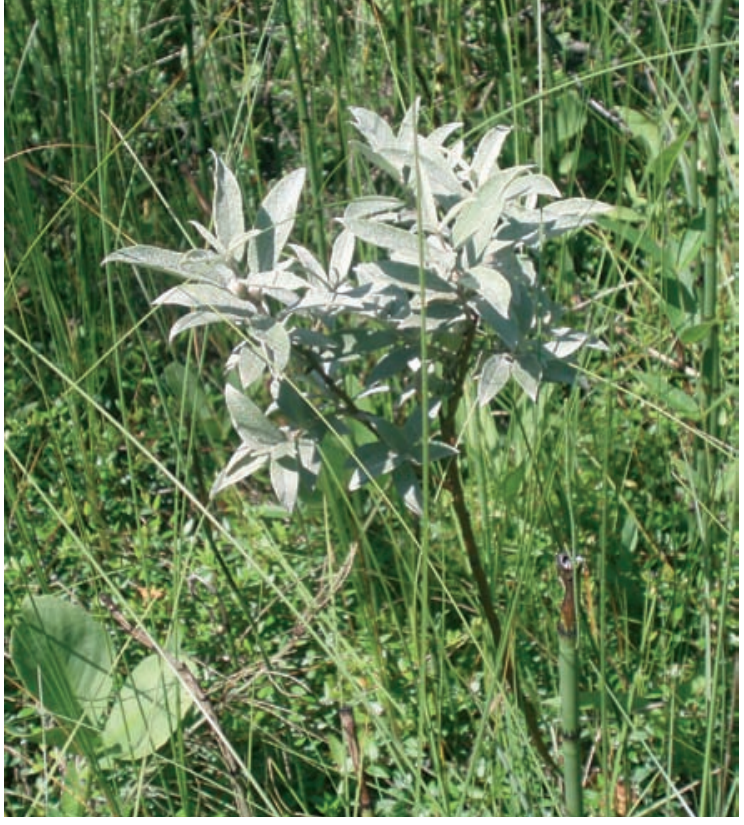

Fig. 3. Salix lapponum specimen in studied area.

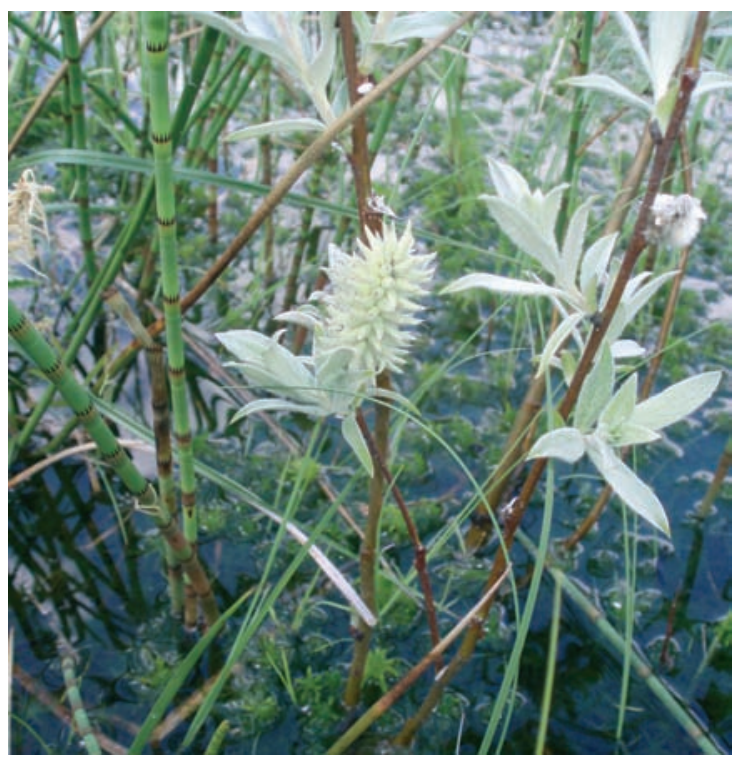

Fig. 5. Fructification of Salix lapponum.

edge (except from its eastern and south-eastern parts) was covered with transitional and valley peat bogs before 1969. The remodelling of the lake's edges associated with the construction of the Wieprz-Krzna Canal caused the isolation of the lake and adjacent peat bog fragments. In 1973 considerable feature changes of the peat bogs inside the ditch and the embankment were observed. The valley peat bogs transformed into transitional ones, and they began to acquire morphological and floristic traits of raising peat bogs (Wo j c i e chowski et al. 1988; Wojciechowski and Fijałkowski, 1998).

The change of the peat bog character probably greatly affected the improvement of the condition of S. lapponum and resulted in the population's increase. 
The character of phytocoenoses, in which Salix lapponum occurred, may prove high requirements of downy willow in terms of habitat conditions, as well as its entering various succession stages.

Blooming of Salix lapponum in Łęczyńsko-Włodawskie Lakeland is in early spring (usually the end of March and beginning of April), which is not confirmed by literature data. The generally cited dates in May-June (Bolliger, 1998; Kaźmierczakowa and Zarzycki, 2001; Kło s ow s c y, 2001; Rutkowski, 2001) probably refer to specimens growing in the center of the dense range of species occurrence (Finland) where climatic conditions are quite different from those observed here (P o d bi elkow ski, 2002).

F i j a k k ow sk i (1958) found that light accessibility apparently affected the conformation and height of downy willow plants; light deficiency was unfavorable, and any activity associated with tree logging and maintenance of peat bog at the thicket stage favored the settlement and development of downy willow. He also determined the classes of Salix lapponum condition, with shrubs up to $1.5 \mathrm{~m}$ height, strongly branched and leafy, considered as the most ripe. Such specimens, according to the studies from 2001-2003, can be found mainly in shady stands, which seems to indicate the connection of the plant's overgrowth with light competition. It is extremely apparent on the peat bog on Lake Bikcze where Salix lapponum growing along with high shrubs and trees reaches up to $2 \mathrm{~m}$, meanwhile at some distance in open area, specimens of only $1 \mathrm{~m}$ height can be seen (acc. to R utk owski, 1998, it is a standard height). Low and inconspicuous shrubs (only to $1 \mathrm{~m}$ of height) occur mainly in unshaded stands where habitat conditions are most similar to natural habitats in the center of the dense range of species occurrence.

Downy willow shows great variability of leaf size, plant height, and shape of leaf blade. F i j a $\nmid \mathrm{k}$ o w sk i (1958), when describing the variability of Salix lapponum, found that the two former traits were closely associated with the habitat change, while the leaf blade shape did not show any of these dependencies, because it resulted from the formation of distant hybrids (mainly with $S$. cinerea and $S$. pentandra).

It was observed during the studies in 2001-2003 that a specimen's height depended on the competition for light with other species, and similarly to the leaf size and shape, on the age of the studied plants.

The reasons for such great differentiation of morphometric traits, namely the leaf blade shape in Salix lapponum, not only in different, but also in the same stands, were not univocally recognized as an effect of crossbreeding with other willow species. Observations made during Salix lapponum blooming at the end of March and beginning of April 2003 did not confirm simultaneous blooming of other willow species accompanying in the stands of the studied species, which excluded the possibility of its pollination with other pollen. However, due to a short study period which included only 3 spring-summer seasons, it could not be concluded that such a process had not occurred in the past and that the seasonal isolation mechanism in the stands within Lubelskie Polesie is a continuous process.

The hypothesis that the studied species grows mainly in a vegetative way in our conditions, which would greatly exclude the possibility to produce inter-species hybrids, was not verified (Kaź mi e r c zakowa and $\mathrm{Z}$ ar z y cki, 2001). Blooming of both male and female specimens in the studied stand as well as great pollen viability did not allow excluding sexual reproduction processes within the downy willow population.

\section{REFERENCES}

Bolliger, Erben, Grau, Heubl, 1998. Krzewy. Leksykon przyrodniczy. / Świat Książki, Warszawa.

Fijałkowski D., 1958. Badania nad rozmieszczeniem i ekologią wierzby lapońskiej (Salix lapponum) na Pojezierzu Łęczyńsko-Włodawskim. /Studies upon distribution and ecology of downy willow (Salix lapponum) in Łęczyńsko-Włodawskie Lakeland. / Fragmenta Floristica et Geobotanika, 3 (2): 89-103.

Fijałkowski D., 1996. Ochrona przyrody i środowiska naturalnego w środkowowschodniej Polsce. / The protection of nature and environment in central-eastern Poland. Wyd. UMCS, Lublin.

Fijałkowski D, Lorens B., 1998. Rośliny borealne we florze Lubelszczyzny / Boreal plants in flora of Lublin region. Ann. UMCS, sect. C, 53: 61-71.

Kaźmierczakowa R., Zarzycki K. (ed.), 2001. Polska Czerwona Księga Roślin. Paprotniki i rośliny kwiatowe. / Instytut Botaniki PAN, Kraków.

Kło s ow s cy S. i G., 2001. Rośliny wodne i bagienne. Ofic. Wyd. MULTICO, Warszawa.

Matuszkiewicz W., 2001. Przewodnik do oznaczania zbiorowisk roślinnych Polski. Wyd. Nauk. PWN. Warszawa.

Mirek Z., Piękoś-Mirkowa H., Zając A., Zając M., 2002. Flowering plants and Pteridophytes of Poland. A checklist. Inst. Botaniki PAN, Kraków.

Mitka J., 1997. Małe, izolowane populacje na skraju zasięgu geograficznego - niektóre procesy ekologiczne i genetyczne. / Small isolated populations at the edge of geographical range - some ecological and genetic processes. Wiad. Bot. 41 (2): 13-34.

Podbielkowski Z., 2002. Fitogeografia części świata. Tom I. Europa, Azja, Afryka. Wyd. Nauk. PWN. Warszawa.

Pogorzelec M., 2004. Wierzba lapońska (Salix lapponum L.) na Polesiu Lubelskim. / Downy willow (Salix lapponum L.) in Polesie Lubelskie Region. Rozprawa doktorska - 
maszynopis w Katedrze Ekologii Ogólnej AR w Lublinie. / Doctor Thesis - manuscript at Depratment of General Ecology, University of Agriculture in Lublin.

Rutkowski L., 1998. Klucz do oznaczania roślin naczyniowych Polski niżowej. Wyd. Nauk. PWN, Warszawa.

Wojciechowski I., Fijałkowski D., 1998. Plan Ochrony Poleskiego Parku Narodowego. Operat ochrony i kształtowania ekosystemów lądowych, Cz. II. Zespoły torfowiskowe. Maszynopis w PPN, Urszulin. / Plan fof Protection of Poleski National Park. Statement of protection and management of the land ecosystems, Part II. Peat bog communities. Manuscript in Poleski National Park, Urszulin.

Wojciechowski I., Wojciechowska W., Czernaś K., Galek J., Religa K., 1988. Changes in phytoplankton over a ten-year period in lakę undergoing de-eutrophication due to surrounding peat bogs. Arch. Hydrobiol. Suppl. 78 (3): 373-387 (Algological Studies 48), Stuttgart.
Populacja wierzby lapońskiej (Salix lapponum L.) na torfowisku nad jeziorem Bikcze (Pojezierze Lęczyńsko-Włodawskie)

\section{Streszczenie}

Celem badań prowadzonych w latach 2001-2003 było określenie struktury i kondycji populacji, a także dokumentacja cech biometrycznych okazów Salix lapponum (wierzby lapońskiej) w jej stanowisku nad jeziorem Bikcze.

Stwierdzono, że liczebność populacji wierzby lapońskiej na torfowisku nad jeziorem Bikcze znacznie wzrosła od lat 1950. Charakter fitocenoz, w których najliczniej występowała Salix lapponum może świadczyć o szerokiej amplitudzie jej wymagań w stosunku do warunków siedliskowych. Osobniki S. lapponum charakteryzowały się dobrą kondycja, odnotowano kwitnienie zarówno okazów męskich jak i żeńskich oraz stwierdzono dużą żywotność ziaren pyłku S. lapponum. Udokumentowano również dużą zmienność wybranych cech biometrycznych osobników badanego gatunku. 
